\title{
Car Ownership, Employment, and Earnings
}

\author{
Steven Raphael \\ Goldman School of Public Policy \\ University of California, Berkeley \\ E-mail: raphael@socrates.berkeley.edu \\ Lorien Rice \\ Department of Economics \\ University of California, San Diego \\ E-mail: 1rice@weber.ucsd.edu
}

We are grateful to Cynthia Bansak, David Card, James A. Dunn, Jens Ludwig, John Quigley, and Sharon Tennyson for many helpful comments. We are especially grateful to Michael Provence for first suggesting the empirical strategy pursued here. This research was supported by a grant from the National Science Foundation, SBR-9709197 and a grant from the Joint Center for Poverty Research. 


\begin{abstract}
In this paper, we attempt to assess whether the positive effects of car ownership on employment outcomes observed in past research are causal. We match state-level data on average car insurance premiums and average per-gallon gas taxes to a nationally representative microdata sample containing information on car ownership and employment outcomes comparable to the those explored in previous research. In OLS regressions that control for observable demographic and human capital variables, we find large differences in employment rates, weekly hours worked, and hourly earnings between those with and without cars. Instrumenting car ownership on insurance and gas tax costs yields estimates of the employment and hours effects of car ownership that are quite close to the OLS estimates. Concerning wages, the IV models yield negative effects of car ownership on wages. This finding is consistent with the hypothesis that employers located in states with high auto maintenance costs must pay compensating differentials to their employees. When we stratify the sample by skill groupings, we find positive significant employment and hours effects for all skill groups, with larger car-employment effects for low-skilled workers and comparable hours effects across skill categories. Again, the IV results for wages yield negative effects that are insignificant for low- and mediumskilled workers and significant for high-skilled workers.
\end{abstract}

JEL Codes: E24, J22, J61, R41 


\section{Introduction}

Regardless of where one resides within a metropolitan area, having access to a car is likely to afford tangible advantages in locating and maintaining employment. For inner-city residents, the continuing spatial decentralization of total employment within metropolitan areas (Kasarda 1989, HUD 1998) and, in particular, of low-skilled employment opportunities (Stoll, Holzer, \& Ihlanfeldt 1998), may render car ownership a virtual necessity for accessing distant job centers. Even for workers residing in suburban communities, the spatially diffuse patterns of suburban economies may be more amenable to commuting by private auto rather than public transit. ${ }^{1}$ In light of these considerations, several researchers have argued for public policy that encourages car-ownership among the low and moderately-skilled (Ong 1996, Ong \& Blumenberg 1998, O’Regan \& Quigley 1998). In particular, Ong \& Blumenberg (1998) suggest that such policies should be an integral component of programs intended to move welfare recipients into sustainable employment.

The evidence offered in support of car-ownership policies consists of empirical studies demonstrating that individuals who own cars are more likely to be employed and, conditional on being employed, earn more than individuals without cars (Holzer et. al. 1994, Ong 1996). While these findings are consistent with causal effects of car ownership, several alternative explanations come to mind. For example, causation may run in the opposite direction; namely, those with jobs can afford cars. Alternatively, car-ownership may be determined in part by unobserved factors that also affect employability-- e.g., skills, or motivation. Given these highly plausible alternative hypotheses, the ability of the existing research to inform policy makers is severely limited.

${ }^{1}$ Suburban land use is often governed by zoning laws dictating strict separation of uses -- e.g., physical separation of residential from commercial or industrial uses of land -- and limiting density through such mechanisms as restrictions on building-height, parking-availability and, for housing, minimum lot sizes (Fischel 1985). Such laws spatially diffuse suburban labor demand, creating multiple employment centers rarely within walking distance of housing and difficult to service by public transit. 
In this paper, we attempt to assess whether the positive effects of car ownership on employment outcomes observed in past research are causal. We match state data on average car insurance premiums and average per-gallon gas taxes to a nationally representative microdata sample containing information on car ownership and employment outcomes. State-level measures of insurance and fuel costs are unlikely to be correlated with unobserved skills or motivation yet are strongly correlated with car ownership rates. Moreover, it is unlikely that employment outcomes aggregated to the state level determine inter-state variation in insurance premiums and gasoline taxes. Hence, these variables provide the necessary exogenous variation in car-ownership rates for an analysis of the effect of having access to a car on labor market outcomes.

We use data from the 1992 and 1993 Survey of Income and Program Participation (SIPP). In OLS regressions that control for observable demographic and human capital variables, we find large differences in employment rates, weekly hours worked, and hourly earnings between those with and without cars. Instrumenting car ownership on insurance and gas tax costs yields estimates of the employment and hours effects of car ownership that are quite close to the OLS estimates. Concerning wages, the IV models yield negative effects of car ownership on wages. This finding is consistent with the hypothesis that employers located in states with high auto maintenance costs must pay compensating differentials to their employees. When we stratify the sample by skill groupings, we find positive significant employment and hours effects for all skill groups, with larger caremployment effects for low-skilled workers and comparable hours effects across skill categories. Again, the IV results for wages yield negative effects that are insignificant for low- and mediumskilled workers and significant for high-skilled workers. Despite the wage results, the employment and hours findings suggest important causal effects of car ownership on employment outcomes. 


\section{Why Should Cars Matter? Theory and a Brief Review of Previous Research}

Several arguments suggest that access to reliable private transportation positively affects employment prospects. To start, commute times are lower using private transportation (Holzer et. al. 1994), reducing the fixed costs of employment, and freeing up time for alternative uses. For workers with strong labor force attachment, this may affect hours worked. For individuals weakly attached, car ownership may figure prominently in the labor force participation decision. Alternatively, relative to those who must rely on public transit, workers with cars can be more flexible in searching for employment. Car owners can cast a wider geographic search net and do not have to restrict their search to jobs with standard time needs that coincide with transit service schedules. Such flexibility is likely to limit the duration of unemployment spells and, hence, the unemployment rate of car-owners relative to those without cars.

Figures 1A and 1B present a more formal depiction of how access to a car affects labor supply decisions in a model where workers allocate time between labor market and non-labor market uses. The time endowment is given by A. Workers convert non-market time into income by supplying time to the labor market. Doing so, however, requires commuting to and from work, a time-consuming activity that is not compensated. Hours supplied to the labor market equals the endowment, A, less time spent in non-market uses and commuting time. The budget constraint for a car owner is given by $\mathrm{ABC}$ while $\mathrm{ADE}$ is the budget constraint without a car. A car affects the budget constraint by reducing commute times (from $\mathrm{AD}$ to $\mathrm{AB}$ ). Here we ignore the monetary costs of car ownership and alternative commute modes, subsuming all differences into commute time. ${ }^{2}$ In this model, workers

\footnotetext{
${ }^{2}$ To be sure, monetary commute costs are not negligible. However, if total commute costs using alternative transportation measured in foregone time (time spent commuting plus time spent earning the income to cover monetary costs) exceeds comparable costs using a car, the analysis above applies.
} 
earn wages equal to their marginal products. Hence, owning a car does not affect wages and the slopes of the non-horizontal portions of the two budget constraints are equal.

For a worker with the preferences given in Figure 1A, losing access to a car is equivalent to a reduction in income, inducing the worker to reduce consumption of all normal goods. To the extent that non-market time and market goods (disposable income) are normal, the increase in commute time is absorbed by a decrease in time allocated to non-market activities (from $\mathrm{H}^{0}$ to $\mathrm{H}^{1}$ ) and a reduction in the consumption of market goods (from $\mathrm{I}^{0}$ to $\mathrm{I}^{1}$ ). In contrast to the standard labor-leisure presentation, however, the decrease in non-market time corresponds to a decrease in hours worked. This results from the fact that forfeited non-market time is not allocated to working but is spent commuting to and from work, as is the time equivalent of the reduction in consumption.

For an individual with relatively strong preferences for non-market uses of time, access to a car may determine whether the individual participates in the paid labor market. This case is depicted in Figure 1B. When facing the budget constraint $A B C$, the worker supplies a small amount of time to the labor market, generating $\mathrm{I}^{0}$ in disposable income. At the initial disposable income/non-market time pair, an increase in the necessary commute time effectively reduces the wage to zero, causing an overwhelming substitution effect towards non-market uses of time. Hence, the individual drops out of the labor market. In summary, for workers with relatively strong preferences for market goods, access to a car in this model unambiguously increases hours supplied to the labor market. For workers with relatively stronger preferences for non-market uses of time, a decrease in commute time afforded by access to a car may be sufficient to draw the individuals into the labor market.

Perhaps a more realistic depiction of how car ownership affects employment outcomes is offered by search models that incorporate a spatial dimension into the search process. Holzer et. al. 
(1994) present a model of spatial search where owning a car is assumed to reduce per-mile travel costs. Increasing the radius of the geographic area searched increases the probability of receiving an acceptable offer, the expected value of wage offers, and the expected value of the commute distance once a match has been found. Searching workers choose an optimal search radius conditional on permile search costs by equating the marginal benefit of search to an exogenously given marginal search cost. The authors show that increasing commute costs per mile decreases the search radius, thus reducing the probability of being employed, increasing the expected duration of unemployment spells, and decreasing the expected value of wages.

The latter prediction, namely that wages are affected by one's ability to traverse distance in search of employment, provides a significant departure from the simple static model of labor supply discussed above. In the model of Holzer et. al. (1994), the authors offer two arguments in defense of the assumption that the expected value of wage offers increases as the size of the geographic area searched increases. First, searching a larger area allows a more thorough sampling of the job opportunities available in the local market. Second, to the extent that a greater search radius results in a longer work commute, workers may demand compensating differentials for lengthy commutes, inducing a positive relationship between search lengths and wages.

The authors, however, abstract from the determination of reservation wages, and hence, overlook several alternative avenues by which car-ownership may affect the expected value of wages. In a model where reservation wages are endogenous, reservation wages for car owners will exceed those of individuals without cars to the extent that searching with a car affects the probability of receiving offers. This would yield a mean difference in the expected value of wages between employed individuals with and without cars. Alternatively, to the extent that workers without cars 
inelastically supply their labor to employers located within the immediate vicinity of their residences, employers may take advantage of their relative immobility and pay wages below marginal revenue product (Raphael and Riker 1999). Holding all else equal, this form of wage discrimination would again induce an earnings difference between workers with and without cars.

Neither of these models address the possibility that owning a car may aid in maintaining employment relationships once matches have been made. Given that keeping a job requires showing up regularly and on time, having access to a reliable car may lower the likelihood of losing a job (and hence the incidence of joblessness) due to attendance problems. While this should not be a problem for those who work and reside along direct, well-serviced public transit corridors, the employment prospects of workers with more complicated commute patterns or with journey-to-work paths not well-serviced by public transit may be particularly sensitive to having a car. For example, for innercity residents that locate suburban jobs, punctuality may be hindered by public transit commutes that require several transfers and entail a high probability of unscheduled delays. A similar story may apply to workers who must make several intermediate trips between home and work -- e.g., having to drop children off at day care or school.

The existing empirical research attempting to estimate the effect of car ownership on employment outcomes implicitly assumes that car ownership is exogenous and regresses employment outcomes on a dummy indicating a car owner and host of other covariates. Using data from the NLSY, Holzer et. al. (1994) find that having access to a car negatively affects the duration of unemployment and positively effects wages. In addition, the authors find a larger car-wage effect for black workers than for white workers, a finding consistent with spatial mismatch in urban labor markets. Using a sample of California AFDC recipients, Ong (1996) finds that AFDC recipients with 
cars are considerably more likely to be employed, and conditional on being employed, work more hours and have higher monthly earnings than recipients without cars.

A major shortcoming of the existing research concerns the lack of attention paid to the issue of causality. A positive correlation between car ownership and employment outcomes such as having a job or monthly earnings is consistent with other hypotheses where cars have no causal effect on labor market prospects. To the extent that car ownership is positively correlated with unobserved ability, the car dummy variable and the residuals in the employment outcome equations will be positively correlated, yielding biased estimates of car-ownership effects. Alternatively, car-ownership may in itself be determined by a steady employment history that permits saving and increases access to the capital necessary for making a large purchase. Both scenarios yield positive empirical correlations between car ownership and employment outcomes yet no causal relationship (from car ownership to employment outcomes) exists. Below, we propose an empirical strategy that directly addresses this criticism.

\section{Empirical Strategy and Data Description}

We investigate the effect of car ownership on three employment outcomes: the probability of being employed, weekly work hours, and hourly wages conditional on being employed. To identify the causal effects of car-ownership, we employ several state-level measures of auto-ownership costs as instruments for car-ownership. Using inter-state variation in state-levied gas taxes and automobile insurance premiums, we estimate the model 


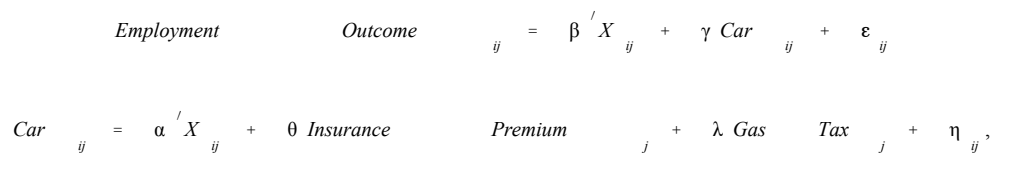

(1)

where $i$ indexes individuals and $j$ indexes states, Employment Outcome $e_{i j}$ is one of the three outcomes analyzed, $X_{i j}$ is a vector of demographic and human capital variables, $\operatorname{Car}_{i j}$ is a dummy variable indicating a car owner, Insurance Premium $_{j}$ is the state average insurance premium, Gas $\operatorname{Tax}_{j}$ is the average state gas tax per gallon, $\beta, \gamma, \alpha, \theta, \lambda$ are parameters, and $\varepsilon_{\mathrm{ij}}$ and $\eta_{\mathrm{ij}}$ are normally-distributed residuals.

To satisfy the conditions for suitable instruments, insurance premiums and gasoline taxes must not affect employment outcomes in any way other than through the impact of these variables on the probability of owning a car. In other words, insurance premiums and gas taxes must be correlated with the probability of owning a car, but must not be correlated with the second stage residual, $\varepsilon_{\mathrm{ij}}$. To assess if these conditions hold, one needs to investigate the processes that determine inter-state differences in insurance premiums and gasoline taxes and evaluate whether the determinants of these variables have direct effects on the employment outcomes analyzed here.

While there is little research directly analyzing inter-state variation in insurance premiums, there is a considerable body of literature on the economics of private passenger automobile insurance that carefully describes the structure of the industry and the determination of premiums. Cummins and Tennyson (1992) note that the principal component of insurance premiums consists of the expected payout the insurer will make during the duration of the policy. This "pure premium," in turn, is determined by two factors: the expected frequency of claims, and the expected severity or cost of the claim. Claim frequency and severity may vary geographically for several reasons. For 
example, there may be variation in the frequency of trips and average trip lengths, differences in traffic congestion, or differences in mean demographic characteristics such as age that affect state accident rates. In addition, inter-state differences in repair costs and wage levels may affect premiums through payouts for property damages and losses resulting from personal injury.

Moreover, variation in regulatory regimes will also yield cross-state dispersion in insurance premiums. Under the McCarron-Ferguson Act of 1945, regulation of the insurance industry was left to the individual states, eventually yielding differences in the institutional structure of auto-insurance markets that are likely to affect premiums. For example, more than half of the states have some form of rate regulation (Suponcic and Tennyson 1998), ranging from "prior approval systems," whereby an insurer's rates must be approved by the state insurance commissioner, to systems where rates are directly set by insurance commissioners or an industry rating bureau. Suponcic and Tennyson(1998) show that rate regulation is associated with pronounced differences in market structure that are likely to affect insurance premiums. For example, in states with rate regulation, there are fewer firms in the market, fewer direct writers or "exclusive dealers" that specialize in auto insurance only and tend to provide coverage at lower costs (Cummins and VanDerhei 1979), and fewer multi-state firms.

In addition, differences in compensation regimes are also likely to affect expected costs to the insurer and the ultimate premiums paid by consumers. Expected payouts for personal injury awards under no-fault compensation systems are likely to be lower than under traditional tort regimes. ${ }^{3}$ Hence, in addition to variation in underlying fundamentals, differences in the institutional environment

\footnotetext{
${ }^{3} \mathrm{No}$-fault insurance states require first-party coverage for personal injury and impose thresholds for the severity of personal injuries below which one is ineligible to pursue lawsuits against a third party (Cummins and Tennyson 1992). Given that personal injury payouts constitute nearly $1 / 3$ of the pure premium, the reduction in expected payout via reduced administrative costs and fewer suits is likely to yield a difference in insurance premiums between states with no-fault regimes and states with tort regimes.
} 
are also important determinants of insurance premiums.

For our purposes, the main question of interest is whether the underlying determinants of insurance premiums in any way directly affect either the probability of employment, usual work hours, or wages. It seems reasonable to argue that inter-state variation in regulatory regimes, trip frequencies and length, and traffic congestion are unlikely to be correlated with the unobservable determinants of employment outcomes. To the extent that such factors are the principal determinants of inter-state variation in premiums, this variable should be a suitable instrument. Inter-state demographic differences, however, in say age, education, gender, race and ethnicity are likely to affect both employment outcomes and insurance premiums. Hence, to the extent possible, our model specifications should include detailed controls for demographic and human capital characteristics.

Geographic variation in local price levels and wages are unlikely to be correlated with unobserved factors that determine employment and hours. These factors, however, are likely to pose problems for our analysis of the effect of car-ownership on wages. To the extent that insurance premiums depend on the regional cost of living (via repair costs, for example), and to the extent that employers in high cost regions must pay compensating wage differentials, insurance premiums may be correlated with the second-stage wage residuals. This would be particularly true if employers in high-premium states pay wage differentials in compensation for high auto insurance costs. This would impart a downward bias to the 2 SLS estimate of car-ownership on wages. ${ }^{4}$ Below, we attempt to directly control for inter-state variation in the cost of living by including estimates of housing costs

${ }^{4}$ If insurance premiums have a negative effect on the probability of owning a car, the predicted value of car-ownership (instrumented on insurance premiums) will be negatively correlated with a factor (the regional cost of living) that positively effects local wages levels. This yields a negative bias to the 2SLS estimate of the effect of car ownership. 
calculated by the Department of Housing and Urban Development (HUD). To the extent that insurance premiums depend directly on local wage levels (a fairly plausible proposition), insurance costs will not be a suitable instrument for car-ownership in a log-wage regression. In light of these caveats, the results for wages presented below should be interpreted with extreme caution.

Concerning fuel taxes, state gas taxes are set within a complex system of institutional relationships designed to plan, finance, and operate the nation's roads. According to Dunn (1998), this system is characterized by two salient organizing principals: (1) a system of inter-governmental transfers whereby federal funds are funneled to the states who bear principal responsibility for building and maintaining roads, and (2) the trust fund principal where revenues collected mainly though federal and state gas taxes are dedicated exclusively to highway infrastructure needs. The Federal-Aid Highway and Highway Revenue Acts of 1956 established a federal trust fund that is financed primarily by the federal gas tax and is explicitly earmarked for highway projects. In addition, this legislation established a cost-sharing plan where the federal government covers 90 percent of interstate highway construction costs and 50 percent of non-interstate road construction costs. For their part, states oversee the construction and maintenance of roads subject to federal regulation and raise money for the state's share of costs through state-imposed gas taxes. Similar to the federal trust fund, the majority of states have exclusive dedication provisions that protect gas tax revenues from competing uses. In particular, 28 states have gas-tax earmarking provisions in either their state constitution or in their body of state law, while eleven others commit receipts to special funds largely devoted to highway projects (Dunn 1998).

This set of institutions suggests that state gas taxes are determined by several factors. First, for federally supported projects, states must raise revenues to meet their matching obligations. 
Second, given that federal funding is limited by federal gas tax receipts and by the appropriations process ${ }^{5}$ states must raise revenues to fully finance state-initiated road projects for which federal funds are not forthcoming. Hence, combined with the explicit earmarking or exclusive dedication provisions present in most states, it seems reasonable to argue that the principal determinants of state gas taxes are project financing needs and the availability of federal funds.

For our purposes, the fact that state gas tax revenues are, for the most part, separated from state general funds suggests that inter-state variation in gas taxes is not determined by inter-state variation in factors that may be correlated with employment rates and the fiscal needs of the states -- e.g., funding for general assistance programs. Hence, combined with the prominent role of the availability of federal funds in determining state needs, these institutional arrangements suggest that the process determining state gas taxes is independent of state-level differences in employment rates and usual hours worked. Nonetheless, to guard against such a possibility we include state unemployment rates in the specifications of all models estimated below. Concerning wages, to the extent that differences in gas taxes contribute to regional differences in the cost of living (both through direct out of pocket expenses and indirect increases in the costs of goods and services) and to the extent that employers must compensate employees for such difference, state gas taxes will not

\footnotetext{
${ }^{5}$ The initial intentions for the federal highway trust fund were that all receipts would be used for interstate and non-interstate highway projects and that the fund would only run small surpluses if any at all. This follows from the explicit earmarking of the fund for highway projects and from the desire to protect the fund from competing budgetary needs. With the passage of the Graham-Rudman-Hollings balanced budget legislation in 1985, however, pressures to reduce the budget deficit led to appropriations levels below the highway trust fund receipts. Consequently, the unspent trust fund balances increased substantially during the post 1985 period (Fahey 1997). In addition, this period witnessed substantial increases in state gas taxes. Between 1980 and 1990, state gas taxes were increased on 136 separate occasions and all but three states increased taxes at least once. Moreover, during this period the average state tax increased from 8.6 cents per gallon to 16.8 cents (Dunn 1993). Hence, the budgetary pressures during the 1980 s coupled with the widespread increases in state gas taxes lend support to the contention that the availability of federal funds is a key determinant of state gas tax levels.
} 
be a valid instrument for car ownership in a log wage equation.

One technical aspect of our empirical strategy that must be addressed concerns the fact that our instruments vary across states yet do not vary across individuals within states. Shore-Sheppard (1998) shows that in IV models where the instruments vary between but not within groups, applying the standard estimate of the parameter covariance matrix may lead to faulty inferences. Specifically, to the extent that the sample is drawn from a population with a grouped structure (or, alternatively stated, to the extent that the second-stage residuals are correlated within group), the 2SLS estimates of the standard errors may be grossly understated.

To account for this possibility, we employ the feasible generalized instrumental variables (FGIV) estimator proposed by Shore-Sheppard. We first estimate the employment outcome models using standard 2SLS and then retrieve the second-stage residuals. We then use these residuals to estimate the within- and between-state variance components and construct the parameter, $\theta_{\mathrm{j}}=$ $\sigma_{\text {within }}^{2} /\left(\sigma_{\text {within }}^{2}+\mathrm{N}_{\mathrm{j}} \sigma_{\text {between }}^{2}\right)$, where $j$ indexes states, $\mathrm{N}_{\mathrm{j}}$ is the within state sample size, $\sigma_{\text {within }}^{2}$ is the within-state variance component, and $\sigma_{\text {between }}^{2}$ is the between-state variance component of the secondstage residuals. This parameter is then used to quasi-difference all of the endogenous and exogenous variables of the model according to the equation, $\mathrm{y}_{\mathrm{ij}}^{\mathrm{d}}=\mathrm{y}_{\mathrm{ij}}-\left(1-\theta_{\mathrm{j}}{ }^{1 / 2}\right) \mathbf{y}_{\mathrm{j}}$, where $\mathrm{y}_{\mathrm{ij}}^{\mathrm{d}}$ is the transformed variable, and $\mathbf{y}_{\mathbf{j}}$ is the state-level average. We then re-estimate the model applying 2SLS to the quasidifferenced data. As noted by Shore-Sheppard (1998), this is equivalent to the implicit data transformation applied when estimating random-effects models. ${ }^{6}$

The data for this project are drawn from several sources. Micro data on employment

${ }^{6}$ Concerning the results below, the parameter estimates using this FGIV estimator do not differ qualitatively from estimation using standard 2SLS and ignoring the grouped error structure. The standard errors using the FGIV estimator are approximately double the estimated standard errors using 2SLS. 
outcomes, car ownership, and basic demographic and human capital characteristics come from the fourth waves of the 1992 and 1993 Survey of Income and Program Participation (SIPP). ${ }^{7}$ These surveys provide large nationally representative samples of individuals along with state of residence identifiers that are used to append the insurance and tax variables. Most importantly, the fourth wave topical modules of the SIPP collect information on up to three cars per household, including the age of the automobile, the financing status, and the person identifier of the car owner within the household. We use this latter variable to explicitly identify individuals that own a car rather than individuals residing in a household where someone owns a car.

Data on state gasoline taxes as of 1993 and 1994 are assembled by the American Petroleum Institute and are measured in cents per gallon paid at the pump. These estimates include both state excise taxes per gallon and sales taxes levied on gasoline purchases. Data on state-level average auto insurance premiums come from the National Association of Insurance Commissioners and reflect average expenditures per insured automobile on liability, collision, and comprehensive coverage. We use the SIPP state identifiers to append this data to the micro data sample. ${ }^{8}$

For our linear probability of employment models and weekly hours models, we restrict the sample to civilians, 16 to 65 years of age, with no work-preventing disabilities. For the hours dependent variable, individuals who are not employed are assigned a value of 0 . In our log-wage

${ }^{7}$ The fourth wave of the 1992 SIPP corresponds to the beginning of 1993 while the fourth wave of the 1993 SIPP corresponds to the beginning of 1994.

${ }^{8}$ Not all states are individually identified in the SIPP. For some small states, identifiers for state group only are provided. These groups include (1) Vermont and Maine, (2) South Dakota, North Dakota, and Iowa, and (3) Montana, Wyoming, Idaho, and Alaska. For observations residing in these state groups, we assigned weighted group averages of the gas tax and insurance premium figures using state populations for the relevant year as weights. 
models, we further restrict the sample to wage and salary workers with complete information. Given that the survey collects complete information on all household automobiles only for those households with 3 or fewer cars, we restrict the sample throughout to individuals residing in such households. After taking into account the other sample restrictions, this restriction eliminates approximately 6 percent of the observations.

We present estimation results for the entire sample, the sample stratified by gender, and the sample stratified by an imputed measure of earnings potential. This latter stratification uses the parameters from a flexibly-specified earnings function estimated with an alternative micro-data sample to impute earnings potential and separate the sample into low-, medium, and high-skilled workers. This imputation is discussed in detail below with the presentation of the results.

\section{Empirical Results}

\section{A. Descriptive Statistics}

Table 1 presents baseline estimates of the effects of car ownership on employment outcomes that are unadjusted for differences in demographic and human capital characteristics. The table provides mean employment outcomes for the entire sample, individuals by car ownership status, and the differences between those with and without cars. We calculate employment rates and weekly hours using the entire sample while mean log wages pertain to employed individuals only. We present separate calculations for the entire sample and the sample stratified by gender.

There are large, statistically significant differences in employment outcomes for both the entire sample and within gender. Concerning employment rates, there is an approximate 27 percentage point overall difference between individuals with cars and those without, with a slightly higher 
difference for men (30 percentage points) than for women ( 24 percentage points). Concerning hours, those with cars work 11 to 16 hours more than those without. Again, the hours differential for men exceeds that for women. Finally, there are substantial differences in the log of hourly earnings between car owners and non-car owners. For the overall sample, the difference in log earnings is approximately .4 , with a difference of .5 for males and .3 for females.

To be sure, differences in observable demographic and human capital characteristics are likely to explain much of the differences in employment outcomes between car owners and non-car owners presented in Table 1. For example, the descriptive statistics in Table A1 show that individuals without cars are slightly more likely to be female, considerably less likely to be married, and considerably more likely to be black or Hispanic than individuals with cars. In addition, car owners have above average educational attainment, are older than average, and are less likely to be in school. Nonetheless, the baseline difference in employment outcomes presented in Table 1 are substantial, suggesting large upper bounds on the premiums associated with owning a car.

As a first pass evaluation of the strength of our instruments, Figures $2 \mathrm{~A}$ and $2 \mathrm{~B}$ present scatter plots of state car ownership rates for 1993 and 1994 against average state auto insurance premiums and state per-gallon gas taxes. We construct state car-ownership rates by averaging the car owner dummy by state and year. The figures also include the predicted relationships between car ownership rates and each of the instruments derived from regressions of the aggregate car-ownership rates on each variable. ${ }^{9}$ For both instruments, there are clear negative relationships between carownership rates and increasing auto maintenance costs. Moreover, the estimated negative effects on

\footnotetext{
${ }^{9}$ These regressions are weighted by the number of observations for the state-year used to compute the proportion that own cars.
} 
aggregate car-ownership rates from the regressions are significant at the .001 level. For insurance premiums in particular, the data points are compactly distributed around the predicted regression line and the negative relationship does not appear to be driven by outlier states. ${ }^{10}$ The data points for the gas tax regressions, on the other hand, are less compactly distributed around the regression line. Nonetheless, there are no obvious outliers driving the negative relationship.

To assess the baseline reduced-form relationship between our instruments and the employment outcomes of interest, Table 2 presents mean car ownership rates and means of the employment outcomes for individuals residing in states with above and below average gasoline taxes and above and below average car insurance premiums. The table also provides baseline IV estimates. The first three columns present means for the sample stratified by state tax rates while the fourth through sixth columns present calculations for the sample stratified by insurance costs. For each instrument, the first column presents means for the low-cost states, the second column presents means for the highcost states, while the third column presents the differences. To the extent that car-ownership has real effects on employment outcomes, the differences in the third and sixth columns should be positive and significant.

We present separate estimates for the entire sample (panel A), for men (panel B), and for women (panel C). The first four rows of each panel present means of car ownership rates and employment outcomes and differences between the two sub-samples stratified by the values of the instruments. The next three rows in each panel present initial IV estimates of the effects of car

\footnotetext{
${ }^{10}$ The three observations in the lower right hand corner of Figure 2A include the 1993 and 1994 observations for Washington, D.C. and the 1993 observation for New York. Dropping these observations and re-estimating the car ownership-insurance premium regression yields an estimate of the insurance premium coefficient of -0.000268 , with a corresponding t-statistics of -7.15 . This is quite close to the estimate provided in Figure 2A.
} 
ownership. These estimates are calculated by taking the ratio of the difference in the employment outcome of interest (in the third and sixth columns) to the comparable difference in car ownership rates. Angrist (1991) and Angrist and Evans (1998) show that this ratio is equivalent to the IV estimate from a just-identified model where the instrument is binary and where the endogenous variable is the sole explanatory variable in the second stage. ${ }^{11}$

Comparable to the results in Figures 2A and 2B, both instruments are strongly negatively correlated with the probability of owning a car and yield differences in car ownership rates that are highly significant. Concerning employment outcomes, there are slight, yet significant, positive differences in employment rates between individuals in low- and high-tax states that are similar for men and women. For high-premium vs. low-premium states, the differences in employment rates are somewhat larger, and is larger for women than for men. Using these differences to calculate baseline IV estimates of the effect of car-ownership on employment probabilities, we find initial estimates using the binary gas tax-instrument that are comparable in magnitude to the difference in employment rates presented in Table 1. For example, the IV estimate for the employment effects presented in the third column suggest an effect of .34 for the entire sample, .34 for males, and .40 for females. These are close to the comparable unadjusted differences in employment rates between those with and without cars of $.27, .30$, and .24 . The IV estimates of the employment effect using the binary insurance premium instrument yield somewhat larger effects for the overall sample (.54), a

\footnotetext{
${ }^{11}$ Specifically, this estimate of the car effect comes from the IV estimate where the first stage equation is given by, $\mathrm{Car}_{\mathrm{i}}=\alpha_{0}+\alpha_{1}$ Treatment $_{\mathrm{i}}+\varepsilon_{\mathrm{i}}$, where "Treatment $\mathrm{i}_{\mathrm{i}}$ is a dummy variable indicating a high insurance (or high gas tax) state, and the second stage equation is given by, Employment Outcome $_{\mathrm{i}}=$ $\beta_{\mathrm{o}}+\beta_{1}$ Car $_{\mathrm{i}}+\eta_{\mathrm{i}}$. The IV estimates in Table 2 are estimates of the parameter $\beta_{1}$ from this second stage regression. The IV estimates for log wages use the car-ownership rate differentials conditional on being employed rather than the differentials for the entire sample that are presented in the table.
} 
comparable effect for males (.34), and a considerably larger employment effect for females (.77). For both instruments, the employment effects are statistically significant.

The IV results for weekly hours yield large, positive, and significant effects of car-ownership on hours worked. Residing in a low-tax state is positively associated with usual hours worked for the entire sample and by gender, as is residing in a low-premium state. Consequently, the base IV estimates of the effect of car ownership on work hours are positive and quite large, with estimates based on the tax instrument of approximately 29 hours for the overall sample, 35 hours for males, and 29 hours for females, and corresponding estimates based on the insurance instrument of 19,13 and 25 hours, respectively. These estimates are, in general, larger than the differences in work hours presented in Table 1 and most likely reflect other underlying differences between workers in high and low-tax states. Concerning wages, log wages are higher in high-tax states relative to low-tax states and are higher in high-premium states relative to low-premium states, yielding uniformly negative IV estimates of the effects of car ownership on wages.

While the IV estimates presented in Table 2 are useful for describing the data, these estimates attribute all responsibility for differences between "treated" and "non-treated" states in employment outcomes to the corresponding difference in car-ownership rates. To the extent that there are differences between high- and low-premium states (or high and low gas-tax states) in variables that affect employment outcomes independently of the effect of car-ownership, such estimates will be biased. Table 3 presents means of observable demographic and human capital variables for the sample stratified by the binary instruments used in Table 2 . In addition, the table presents means of several state-level variables that are likely to affect either the probability of employment, work hours, or wages. There are several differences in the variables listed that may bias the simple IV estimate 
presented in Table 2. For example, the unemployment rate at the time of the survey is higher in highrelative to low-tax states and in high-premium relative to low-premium states. This should impart an upward bias on the employment, hours, and wage effects in Table 2.

In addition, low-tax states and low-premium states have lower unionization rates than their high-tax and high-premium counterparts. This pattern is probably due to the disproportionate representation of southern states among the group with below average car ownership costs. Hence, the negative IV estimates for wages in Table 2 may in part reflect lower unionization rates in low-tax and low-premium states. An additional pattern of interest concerns difference in housing costs. We append state-level Fair Market Rent data for 1993 and 1994 calculated by the Department of Housing and Urban Development (HUD) to our microdata set to gauge differences across states in the cost of living. ${ }^{12}$ Differences in housing costs (as measured by the Fair Market Rents) between low- and high-tax and low- and high-premium states are quite large and suggest that failure to control for differences in the cost of living will impart a large negative bias to the IV estimates of the effects of car ownership on wages. For example, average Fair Market Rents in high-tax states exceed those in low-tax states by more than $\$ 100$, while Fair Market Rents in high insurance states exceed those in low-insurance states by more than $\$ 170$.

The means presented in Table 3 suggest that there may be important differences across states in factors that affect the three employment outcomes and that are correlated with our chosen

\footnotetext{
${ }^{12}$ Fair Market Rents are estimates of the cost of a standard two-bedroom apartment at the 45th percentile of the local rent distribution. These are estimates of gross rent that include the shelter rent plus the cost of all utilities, except telephones. These calculations are used to determine the size of Section 8 housing subsidies and units that are eligible for subsidy under the program. This data is calculated at the PMSA and county level by HUD. We use estimates of corresponding population counts to calculate population weighted state averages. These state-level averages are the figures appended to the microdata.
} 
instruments. Hence, more fully specified models are needed. In addition, the binary presentation of the instruments in Tables 2 and 3 does not make full use of the inter-state variation in these variables. In the next sub-section we incorporate the variables listed in Table 3 and use the actual state values of gas taxes and insurance premiums as instruments for car ownership.

\section{B. OLS and 2SLS Results}

Table 4 presents OLS and 2SLS estimates of the effects of car ownership on each of the three employment outcomes for the entire sample. ${ }^{13}$ In these models we incorporate the explanatory variables listed in Table 3 and use the full inter-state variation in gas taxes and insurance premiums as instruments. Specifications of the linear employment probability models and hours models include all variables listed in Table 3 except for the region dummies, the union indicator, and the Fair Market Rent variable (our cost of living proxy). The log-wage regressions include all listed variables less the region dummies. We do not include the region dummy variables in our model specification since this eliminates much of the variation in our instruments. For each outcome, the table first presents the OLS results followed by the second-stage parameters from the 2SLS model. The first-stage, carownership regression results are presented in appendix Table A2.

Beginning with the OLS results, controlling for observable human capital and demographic variables explains a considerable portion of the unadjusted differences in employment, hours, and wages. Nonetheless, substantial effects remain. For example, after adjusting for observable characteristics there is a 16.8 percentage point difference in the employment rates between car owners and non-car owners, compared with an unadjusted difference from Table 1 of 27 percentage points. In addition, the OLS results indicate that owning a car increases work hours by a bit more than 7

\footnotetext{
${ }^{13}$ Recall, the 2SLS results are the results from FGIV estimator outlined above.
} 
hours and wages by nearly 11 percent, compared with unadjusted effects of 14 hours and 40 percent, respectively. All of the car coefficients from the OLS regressions are significant at the one percent level.

Before turning to the 2SLS estimates of the car-ownership effects, a brief discussion of the results from the first-stage regressions reported in Table A2 is necessary. For all three models, each instrument exerts a negative effect on the probability of owning a car and each is independently significant. In the first-stage results for the employment model and hours model, the F-statistics for the test of the joint significance of the two instruments are quite large (95 for the employment model and 107 for the hours model). ${ }^{14}$ The F-statistics for the comparable joint significance test for the wage model is substantially smaller (7.065). Nonetheless, the effects of gas taxes and insurance premiums are still jointly significant at the .001 level. Hence, the instruments are strongly correlated with the probability of owning a car even after conditioning on a large set of covariates. Concerning the other variables in the specification, there are several interesting patterns. For example, blacks and Hispanics are considerably less likely to own a car. In addition, the probability of owning a car increases with one's level of educational attainment and increases at a decreasing rate in age.

Turning back to the results in Table 4, the 2SLS estimate of the effect of car-ownership on the probability of being employed (.146) is quite close to the estimates from OLS (.168). Moreover, this point estimate is significant at the 5 percent level. Since we use two instruments in the first-stage regression, we are able to perform a test of the over-identifying restriction, the results of which are

\footnotetext{
${ }^{14}$ While the first stage regression for the employment and hours models are estimated on the same sample, the parameters differ slightly due to differences in the factor used to difference away a portion of the inter-state variation in the data. Recall, the differencing factor, $\theta_{\mathrm{j}}$, employs estimates of the betweenand within-state variance components from the second-stage residuals using initial 2SLS estimates.
} 
reported for each outcome in the last row of the table. For the employment outcome, the test fails to reject the over-identification restriction, suggesting that the strong results for employment are not sensitive to the choice of instruments.

The 2SLS results for hours yield a significant positive effect of car ownership on work hours of approximately 11 hours. While this point estimate is somewhat larger than the OLS estimate of 7.4 hours, the large standard error suggests that this deviation may be due in large part to the imprecision of the point estimate. Nonetheless, we are able to measure a significant positive hours effect suggesting a real role of access to an automobile on employment and hours. Again, the test of the over-identification restriction fails to reject the restriction at the 10 percent level.

Concerning the 2SLS results for log wages, instrumenting on gas taxes and insurance premiums yields a negative, significant effect of car-ownership on wages. These results are subject to several alternative interpretations. To start, variation in the costs of car-ownership across states may make it necessary for employers in high-cost states to pay wage differentials in compensation for the contribution of these factors to the regional cost of living. To the extent that this is the case, insurance costs and gasoline taxes belong in the second stage regression and hence, the 2SLS model estimated in the final column of Table 4 is mis-specified. Alternatively, these costs may be spuriously correlated with other factors not captured by our measure of inter-state variation in housing costs that affect the local cost of living. Finally, it could be that our estimates are correct and that owning a car reduces wages. This, however, seems highly implausible. We suspect that estimating the wage effect of car ownership requires an alternative identification strategy than that employed here.

With respect to the other variables in the model, most of the point estimates are what one would expect. Blacks are less likely to be employed than whites and earn considerably less per hour. 
We observe a similar pattern for females and, to a lesser extent, Hispanics. The state unemployment rate exerts a negative effect on the probability of being employed, on hours, and on wages, while state Fair Market Rents have a strong effect on log-wages.

Table 5 presents comparable results where we estimate each model separately by gender. Here, we only report the estimated coefficients on the car-owner dummy, the F-statistics for the test of the cumulative significance of the instruments in the first-stage regression, and the test-statistics and P-value for the test of the over-identification restriction. The estimation results for the other background variables do not differ qualitatively from those presented in Table 4 and hence are not reported. We reproduce the results from the pooled sample for ease of comparison.

Again, for both men and women the point estimates of the effect of car ownership on the probability of being employed are similar for the OLS and 2SLS models. The employment effects are considerably larger for women than men and the 2SLS results are significant for women only. For both men and women, we fail to reject the over-identification restriction at the 5 percent level. We observe similar patterns for the hours models. The hours effect of owning a car is slightly larger for women than for men and instrumenting increases the point estimates. Here, the 2SLS results are significant for both men and women. Concerning wages, we find comparable positive effects on the log of hourly wages in the OLS regressions that turn negative (and for women, significant) when we instrument on gasoline taxes and insurance premiums.

In summary, the OLS and 2SLS results both indicate a strong positive effect of car-ownership on the probability of being employed and on work hours that does not appear to be sensitive to the choice of instrument. The results for the employment effect of car ownership indicate substantially larger effects on the labor force participation decisions of women than men. The hours effects are 
comparable across gender. Finally, our OLS and 2SLS estimates for the effect of car-ownership on wages are at odds.

\section{Testing for Differential Effects Over the Skill Distribution}

The results from the previous section indicate sizable causal effects of having access to a car on the probability of employment and on weekly work hours. However, there are several reasons to suspect that the size of these effects may not be uniform across workers grouped broadly by skill or earnings potential. For example, it seems reasonable to argue that job search among relatively lessskilled workers is less formal than the search process of highly-skilled workers, involving more pounding of the pavement and submitting applications in response to help-wanted signs. In addition, highly-skilled workers are less constrained in choosing residential locations due to a greater command over resources and hence, may disproportionately locate in jobs-accessible communities. This would render the employment prospects of low-skilled workers particularly sensitive to whether they have access to a car.

To explore these possibilities, in this section we impute earnings potential for all workers in our sample, stratify the sample into thirds according to this distribution, and then estimate separate models for each sub-sample comparable to those in the previous section. To impute earnings potential, we employ a strategy similar to Card (1996) and Raphael (1999). First, we combine the 12 Current Population Survey (CPS) Outgoing Rotation Group (ORG) files for 1993 and restrict the sample to wage and salary worker 16 to 65 years of age. Next, we use this nationally representative sample of workers to estimate a flexibly-specified log-wage regression including controls for age, 
educational attainment, race, ethnicity, gender, and several interactions between these variables. ${ }^{15}$ We then use the parameters from this earnings function to impute potential earnings for all workers in the SIPP sample. ${ }^{16}$ The sample is then stratified by thirds.

Table 6 presents means of the dependent and explanatory variables by position within our imputed earnings distribution. Not surprisingly, workers falling into the bottom third are considerably less likely to own a car, are less likely to be employed, work fewer hours, and earn less per hour than workers in the upper two thirds. Similar differences are observed between workers in the middle and upper thirds of the earnings distribution. In addition, as we move up the imputed earnings distribution, the average age increases, the proportions female and minority decrease, and the average level of educational attainment increases. There are no noticeable differences in state unemployment rates, cost of living (Fair Market Rents), gas taxes, or average insurance premiums experienced by the three groups of workers. In addition, the geographic distributions across the four regions of the country are similar.

Table 7 presents OLS and 2SLS results for the three groups of workers comparable to the results presented in Tables 4 and 5 for the entire sample. Again, to conserve space here we only report the coefficients on car ownership and, for the 2SLS results, the test-statistics for tests of

\footnotetext{
${ }^{15}$ The regression specification includes age, age-squared, six education dummies, dummies for female, black, and Hispanic, interactions between each age variable and the education, female, black, and Hispanic dummies, interactions between the education dummies and the female, black, and Hispanic dummies, and interactions between female and black and female and Hispanic.

${ }^{16}$ While the imputed earnings function will be determined in large part by the skill endowments of each person in the sample, the inclusion of race, ethnicity, and gender in the earnings function suggests that such factors as discrimination and accessibility to employment may also play a role. Consequently, our imputed earnings distribution is more a gauge of the structure of wages and hence, earnings potential than a pure measure of skills valued by the market.
} 
cumulative significance of the instruments in the first stage and the tests of the over-identifying restriction. We present the first-stage coefficient estimates on the instruments for each model in appendix Table A3. Starting with the OLS results for employment, the car-ownership effect declines monotonically as we move across the distribution of earnings potential, with a point estimate for the lower third (.213) that is more than double the point estimate for the top third (.099). In the OLS employment regressions, car ownership is significant at one percent in all three models. Instrumenting on gas taxes and insurance premiums again yields 2SLS estimates of the caremployment effect that are similar to the OLS estimates in all three sub-samples. All of the 2SLS estimates of the car-employment effect are significant at 10 percent with the estimates for the middle and upper third sample significant at 5 percent. While the point estimates from the 2SLS models are still larger for workers with lower earnings potential, the variation across samples in this coefficient is less than when the models are estimated by OLS.

The pattern of OLS results for hours is similar to that for the employment models (declining as we move across the distribution of imputed earnings), with estimated car-hours effects of approximately 9,7 , and 5 hours for the lower, middle, and upper thirds of the distribution, respectively. The 2 SLS results, however, yield a different pattern. While the OLS and 2SLS results are comparable for the lower-third sub-sample, instrumenting considerably increases the point estimate of the car-hours effect for the middle and upper thirds. In fact, for individuals in the upperthird sub-sample, instrumenting more than doubles the estimate of the car-hours effect over the comparable OLS estimate. Hence, while there appears to be some evidence of decreasing car employment effects as imputed earnings increase, there is little evidence that this sort of pattern exists for the effects on work hours. 
Again, the wage models yield mixed results, with sizable and significant car-wage effects in the OLS regressions that do not vary uniformly with earnings potential, and negative 2SLS estimates that are insignificant for the lower thirds and significant and negative for the upper third. The latter finding suggests that the negative significant effects observed for the entire sample are being driven by workers in the upper third of the earnings distribution. To the extent that workers in this portion of the distribution are more geographically mobile than workers in the lower thirds, this pattern lends support to the conjecture that the negative wage results are being driven by compensating wage differentials that offset regional variation in the cost of living.

Concerning the first-stage results presented in Table A3, each instrument is individually significant in all models with the exception of gas taxes in the wage model for the upper third of the imputed earnings distribution. For the employment and hours models, the tests of the joint significance of the instruments all yield F-statistics in excess of 35. None of the tests of the overidentifying restriction reject the restriction at the 5 percent level of confidence and in only one model (middle-third hours) is the restriction rejected at the 10 percent level. Hence, similar to the full sample results, the 2SLS estimates of the effect of car ownership on employment outcomes are not sensitive to the choice of instruments.

One interesting pattern that emerges from Table A3 concerns the coefficients on gas taxes. For all three outcomes, the negative effect of state gas taxes on the probability of owning a car declines as we move up the distribution of imputed earnings. For the employment and hours models, the negative effect of taxes on the probability of owning a car among the lower third sample is almost twice the negative effect observed for the upper third of the sample. A similar pattern is observed in the wage models. 
In summary, stratifying the sample by earnings potential yields some evidence of differential effects of car ownership on the probability of employment, with larger effects for workers in the bottom of the distribution. While OLS results indicate differential effects on work hours, the 2SLS results suggest strong positive effects of car-ownership that are uniform across groups. Finally, the mixed results for wages observed for the entire sample reproduce when the sample is stratified by earnings potential.

\section{Conclusion}

The results of this paper indicate that having access to a car is an important determinant of labor market outcomes. We find quite strong effects of car ownership on the probability of employment and usual hours worked per week. Moreover, estimates of the effect of cars on these outcomes are comparable in both OLS regressions that ignore the potential endogeneity of car ownership and 2SLS models that employ state-level variation in car operation costs as instruments. Despite our weak 2SLS results for wages, the strong positive effect of cars on wages in the OLS models, coupled with our stated reservations concerning the validity of our instruments in a model of wage determination, suggest that further research on the relationship between car ownership and wages is warranted. Moreover, given the finding that correcting for the endogeneity of car ownership does not appreciably alter our point estimates of the effects on employment and hours (outcomes for which our instruments are better suited), perhaps alternative identification strategies better suited for an analysis of wages would yield comparable results.

A direction for future research concerns the large differences by race and ethnicity in car ownership rates. The results from our car-ownership regressions indicate that, even after 
conditioning on observable human capital characteristics, there is a 16 percentage point difference between the car ownership rates of whites and blacks and a 9 percentage point difference between whites and Latinos. Given the finding of a strong effect of access to a car on the probability of being employed, these patterns may provide a partial explanation of the persistent racial and ethnic difference in employment ratios and unemployment rates observed in the U.S. 


\section{References}

Angrist, Joshua D. (1991), "Grouped-Data Estimation and Testing in Simple Labor Supply Models," Journal of Econometrics, 47(2): 243-266.

Angrist, Joshua D. and William N. Evans (1998), "Children and Their Parent's Labor Supply: Evidence from Exogenous Variation in Family Size," American Economic Review, 88(3):450-477.

Card, David (1996), "The Effect of Unions on the Structure of Wages: A Longitudinal Analysis," Econometrica, 64(4): 957-979.

Cummins, J. David and Sharon Tennyson (1992), "Controlling Automobile Insurance Costs," Journal of Economics Perspectives, 6(2): 95-115.

Cummins, J. David and Jack VanDerhei (1979), "A Note on the Relative Efficiency of Property Liability Insurance Distribution Systems," Bell Journal of Economics, 10: 709-719.

Dunn, James A. Jr. (1993), "The Politics of Motor Fuel Taxes and Infrastructure Funds in France and the United States," Policy Studies Journal, 21(2): 271-284.

Dunn, James A. Jr. (1998), Driving Forces: The Automobile, Its Enemies, and the Politics of Mobility, Brookings Institution Press: Washington, DC.

Fahey, James (1997), "How the Highway Trust Fund Has Changed and the Impact on Road and Bridge Funding Needs," The Road Information Program, Washington, DC.

Fischel, William (1985), The Economics of Zoning Laws, Johns Hopkins: Baltimore, MD.

Holzer, Harry J.; Ihlanfeldt, Keith R.; and David L. Sjoquist (1994), "Work, Search, and Travel Among White and Black Youth," Journal of Urban Economics, 35: 320-345.

Kasarda, John (1989), "Urban Industrial Transition and the Underclass," The Annals of the American Academy of Political and Social Science, 501: 26-47.

Ong, Paul (1996), "Work and Automobile Ownership Among Welfare Recipients," Social Work Research, 20(4): 255-262.

Ong, Paul and Evelyn Blumenberg (1998), "Job Access, Commute and Travel Burden Among Welfare Recipients," Urban Studies, 35(1): 77-94.

O'Regan, Katherine M. and John M. Quigley (1998), "Cars for the Poor," Access, 12(Spring): 22.

Raphael, Steven (1999), "Estimating the Union Earnings Effect Using a Sample of Displaced 
Workers," forthcoming, Industrial and Labor Relations Review.

Raphael, Steven and David A. Riker (1999), "Geographic Mobility, Race, and Wage Differentials," Journal of Urban Economics, 45(1): 17-46.

Shore-Sheppard, Lara (1998), "The Precision of Instrumental Variables With Grouped Data," unpublished manuscript.

Stoll, Michael A.; Holzer, Harry J. and Keith Ihlanfeldt (1998) "Within Cities and Suburbs: Racial Residential Concentration and the Spatial Distribution of Employment Opportunities Within Sub-Metropolitan Areas," Working paper, Department of Policy Studies, UCLA.

Suponcic, Susan J. and Sharon Tennyson (1998), "Rate Regulation and the Industrial Organization of Insurance," in Bradford, David F.(editor) The Economics of Property-Casualty Insurance, The University of Chicago Press: Chicago.

U.S. Department of Housing and Urban Development (1998), The State of the Cities, Office of Policy Development and Research, Washington, DC. 


\section{Figure 1}

A. Effect on Work Hours

Disposable Income

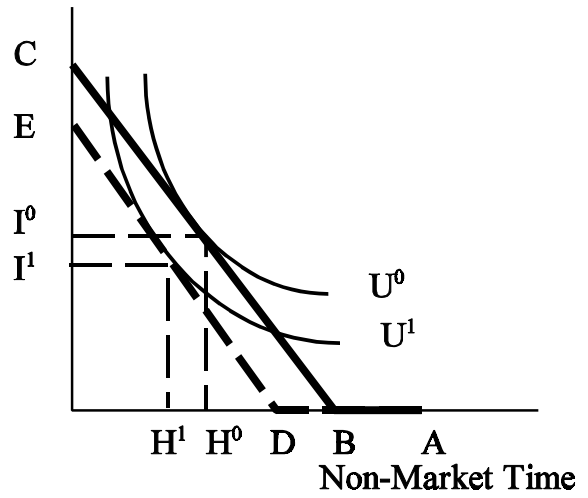

B. Effect on Labor Force Participation

Disposable Income

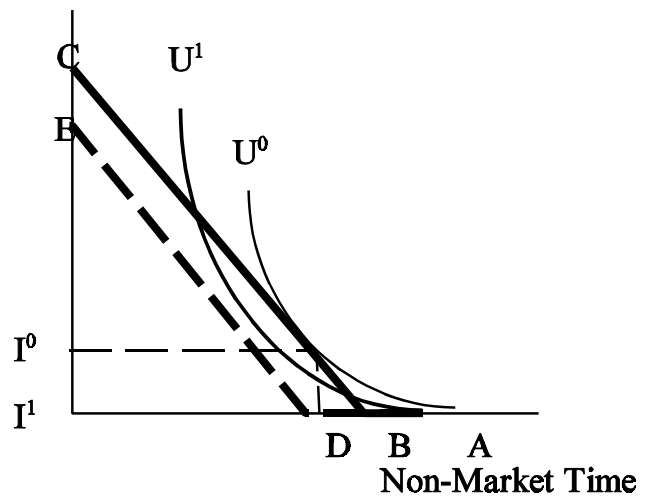


Figure 2A

Scatter Plot of State Car-Ownership Rates Against Average Insurance Premiums

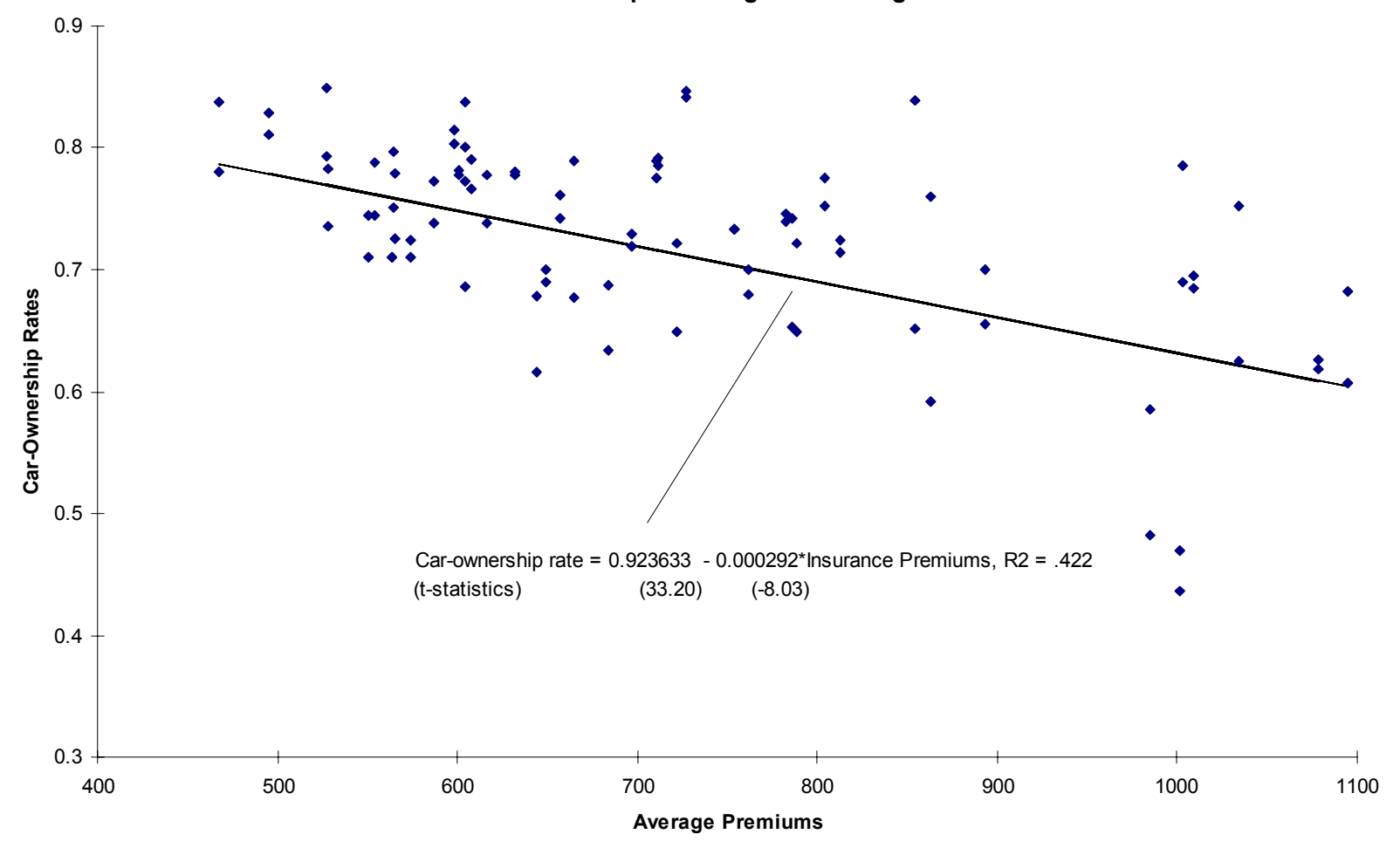

Figure 2B

Scatter Plot of State Car-Ownership Rates Against Per-Gallon Gas Taxes

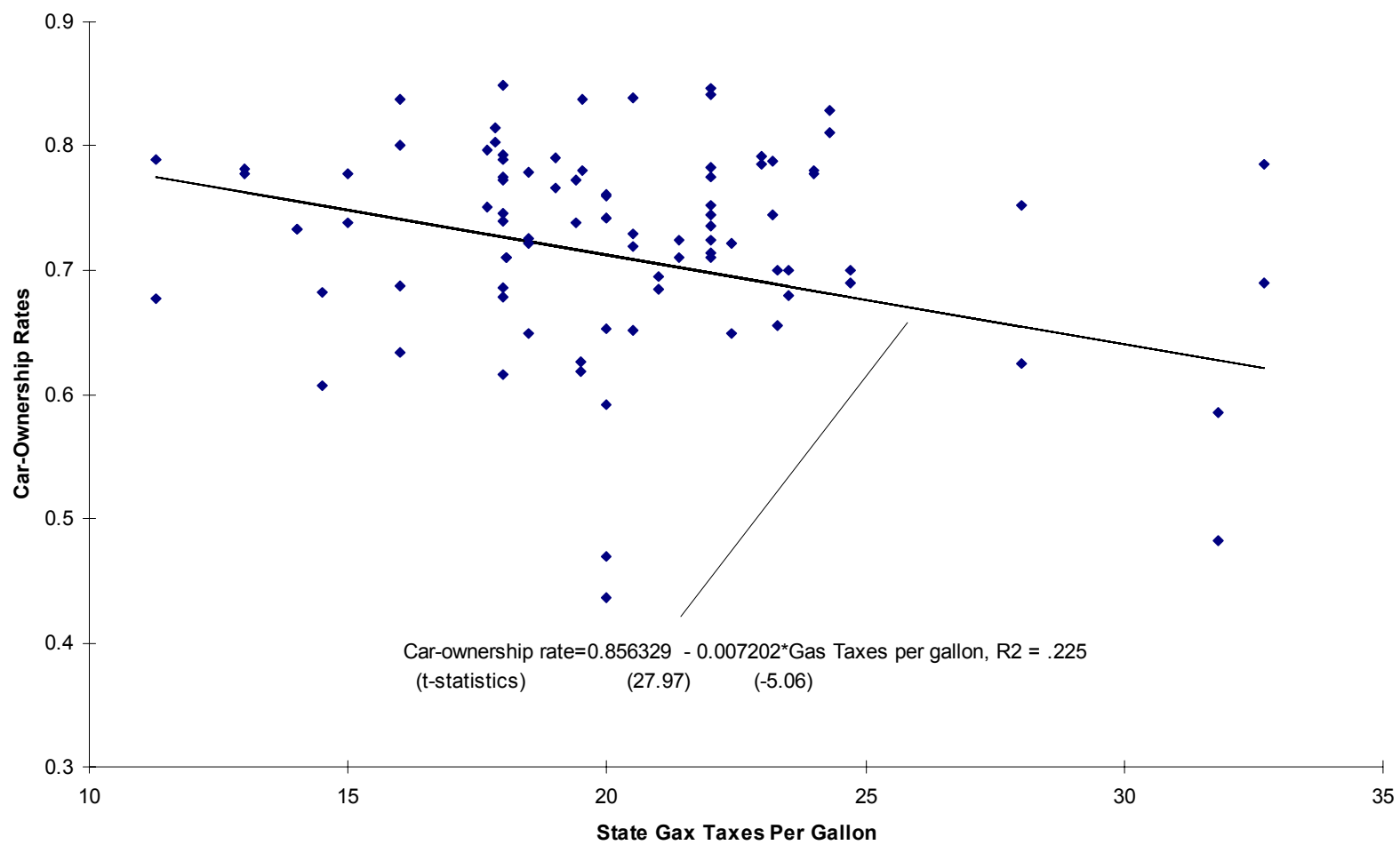




\begin{tabular}{|c|c|c|c|c|}
\hline \multicolumn{5}{|c|}{$\begin{array}{l}\text { Table } 1 \\
\text { Means Employment, Work Hours, and Hourly Wages by Gender and Car Ownership } \\
\text { Status }\end{array}$} \\
\hline & All & With Cars & Without Cars & Difference \\
\hline \multicolumn{5}{|l|}{ All } \\
\hline Employed & $.715(.002)$ & $.799(.002)$ & $.528(.004)$ & $.271(.004)$ \\
\hline Work Hours & $28.687(.091)$ & $32.887(.101)$ & $19.265(.168)$ & $13.622(.188)$ \\
\hline Log Wages ${ }^{\mathrm{a}}$ & $2.278(.003)$ & $2.368(.004)$ & $1.981(.006)$ & $.387(.007)$ \\
\hline $\mathrm{N}$ & 47,244 & 33,322 & 13,922 & - \\
\hline \multicolumn{5}{|l|}{ Men } \\
\hline Employed & $.785(.002)$ & $.875(.003)$ & $.575(.006)$ & $.300(.005)$ \\
\hline Work Hours & $33.642(.131)$ & $38.530(.269)$ & $22.250(.131)$ & $16.279(.265)$ \\
\hline Log Wages $^{\mathrm{a}}$ & $2.388(.004)$ & $2.494(.005)$ & $2.025(.010)$ & $.469(.010)$ \\
\hline $\mathrm{N}$ & 21,664 & 15,697 & 5,967 & - \\
\hline \multicolumn{5}{|l|}{ Women } \\
\hline Employed & $.653(.003)$ & $.729(.003)$ & $.488(.006)$ & $.241(.006)$ \\
\hline Work Hours & $24.260(.120)$ & $27.734(.140)$ & $16.728(.209)$ & $11.006(.251)$ \\
\hline Log Wages $^{\mathrm{a}}$ & $2.159(.004)$ & $2.230(.005)$ & $1.937(.009)$ & $.293(.010)$ \\
\hline $\mathrm{N}$ & 25,580 & 17,625 & 7,955 & - \\
\hline
\end{tabular}


Table 2

Preliminary IV Estimates of the Effects on Employment, Hours and Log-Wages of Car Ownership Using State Insurance Costs and Gas Taxes as Instruments, All Workers and by Gender

\begin{tabular}{|c|c|c|c|c|c|c|}
\hline & $\begin{array}{l}\text { Low-Tax } \\
\text { States }\end{array}$ & $\begin{array}{l}\text { High-Tax } \\
\text { States }\end{array}$ & $\begin{array}{l}\text { Difference } \\
\text { and IV } \\
\text { Estimates }\end{array}$ & $\begin{array}{l}\text { Low- } \\
\text { Insurance } \\
\text { States }\end{array}$ & $\begin{array}{l}\text { High- } \\
\text { Insurance } \\
\text { States }\end{array}$ & $\begin{array}{l}\text { Difference } \\
\text { and IV } \\
\text { Estimates }\end{array}$ \\
\hline \multicolumn{7}{|l|}{ A. All } \\
\hline $\begin{array}{l}\text { Car Owners } \\
\text { Employed } \\
\text { Hours } \\
\text { Log Wages }^{\mathrm{a}}\end{array}$ & $\begin{array}{r}.710(.003) \\
.721(.003) \\
29.219(.131) \\
2.235(.005)\end{array}$ & $\begin{array}{r}.674(.003) \\
.709(.003) \\
28.177(.128) \\
2.319(.005)\end{array}$ & $\begin{array}{r}.036(.004) \\
.012(.004) \\
1.042(.183) \\
-.084(.006)\end{array}$ & $\begin{array}{r}.729(.003) \\
.736(.003) \\
29.391(.126) \\
2.234(.004)\end{array}$ & $\begin{array}{r}.654(.003) \\
.695(.003) \\
27.985(.132) \\
2.325(.005)\end{array}$ & $\begin{array}{r}.075(.004) \\
.040(.004) \\
1.406(.183) \\
-.091(.006)\end{array}$ \\
\hline $\begin{array}{l}\text { IV Estimates } \\
\text { Employed } \\
\text { Hours } \\
\text { Log-Wages }^{\mathrm{b}}\end{array}$ & $\begin{array}{l}- \\
- \\
-\end{array}$ & $\begin{array}{l}- \\
- \\
-\end{array}$ & $\begin{array}{r}.343(.112) \\
29.198(5.21) \\
-2.446(.419)\end{array}$ & $\begin{array}{l}- \\
- \\
-\end{array}$ & $\begin{array}{l}- \\
- \\
-\end{array}$ & $\begin{array}{r}.547(.055) \\
18.856(2.35) \\
-1.534(.181)\end{array}$ \\
\hline \multicolumn{7}{|l|}{ B. Men } \\
\hline $\begin{array}{l}\text { Car Owners } \\
\text { Employed } \\
\text { Hours } \\
\text { Log Wages }^{\mathrm{a}}\end{array}$ & $\begin{array}{r}.718(.004) \\
.791(.004) \\
34.279(.189) \\
2.356(.006)\end{array}$ & $\begin{array}{r}.683(.004) \\
.779(.004) \\
33.045(.183) \\
2.419(.006)\end{array}$ & $\begin{array}{r}.035(.006) \\
.012(.005) \\
1.234(.263) \\
-.063(.009)\end{array}$ & $\begin{array}{r}.740(.004) \\
.798(.004) \\
34.180(.181) \\
2.359(.006)\end{array}$ & $\begin{array}{r}.660(.005) \\
.771(.004) \\
33.111(.190) \\
2.418(.007)\end{array}$ & $\begin{array}{r}.079(.006) \\
.027(.005) \\
1.068(.263) \\
-.059(.009)\end{array}$ \\
\hline $\begin{array}{l}\text { IV Estimates } \\
\text { Employed } \\
\text { Hours } \\
\text { Log-Wages }^{\text {b }}\end{array}$ & $\begin{array}{l}- \\
- \\
-\end{array}$ & $\begin{array}{l}- \\
-\end{array}$ & $\begin{array}{r}.343(.148) \\
34.659(7.54) \\
-1.602(.402)\end{array}$ & $\begin{array}{l}- \\
- \\
-\end{array}$ & $\begin{array}{l}- \\
- \\
-\end{array}$ & $\begin{array}{r}.341(.066) \\
13.444(3.06) \\
-.844(.172)\end{array}$ \\
\hline \multicolumn{7}{|l|}{ C. Women } \\
\hline $\begin{array}{l}\text { Car Owners } \\
\text { Employed } \\
\text { Hours } \\
\text { Log Wages }^{\mathrm{a}}\end{array}$ & $\begin{array}{r}.703(.004) \\
.660(.004) \\
24.786(.172) \\
2.109(.006)\end{array}$ & $\begin{array}{r}.667(.004) \\
.646(.004) \\
23.750(.169) \\
2.210(.006)\end{array}$ & $\begin{array}{r}.036(.006) \\
.015(.005) \\
1.036(.241) \\
-.101(.009)\end{array}$ & $\begin{array}{r}.719(.004) \\
.680(.004) \\
25.155(.167) \\
2.103(.006)\end{array}$ & $\begin{array}{r}.649(.004) \\
.626(.004) \\
23.361(.174) \\
2.221(.006)\end{array}$ & $\begin{array}{r}.070(.005) \\
.054(.005) \\
1.795(.241) \\
-.117(.009)\end{array}$ \\
\hline $\begin{array}{l}\text { IV Estimates } \\
\text { Employed } \\
\text { Hours } \\
\text { Log-Wages }^{\text {b }}\end{array}$ & $\begin{array}{l}- \\
-\end{array}$ & $\begin{array}{l}- \\
-\end{array}$ & $\begin{array}{r}.405(.163) \\
28.749(7.07) \\
-3.425(.883)\end{array}$ & $\begin{array}{l}- \\
- \\
-\end{array}$ & $\begin{array}{l}- \\
- \\
-\end{array}$ & $\begin{array}{r}.773(.093) \\
25.520(3.52) \\
-2.433(.410)\end{array}$ \\
\hline $\begin{array}{l}\text { IV estimates fo } \\
\text { high/low differ } \\
\text { from the fourth } \\
\text { a. Figures are c } \\
\text { b. The IV estim } \\
\text { than the total p }\end{array}$ & $\begin{array}{l}\text { he effect of car c } \\
\text { ce in the employ } \\
\text { aves of the } 1992 \\
\text { ditional on being } \\
\text { es for log-wages } \\
\text { ulation. }\end{array}$ & $\begin{array}{l}\text { wnership on the } \\
\text { ment outcome t } \\
\text { and } 1993 \text { Surve } \\
\text { employed. } \\
\text { are calculated }\end{array}$ & $\begin{array}{l}\text { labor market ou } \\
\text { the high/low di } \\
\text { of Income and } \\
\text { ing car-ownersl }\end{array}$ & $\begin{array}{l}\text { omes are ca } \\
\text { erence in car } \\
\text { rogram Part } \\
\text { p rate differe }\end{array}$ & $\begin{array}{l}\text { lated by taking } \\
\text { wnership rates. } \\
\text { pation. } \\
\text { es for the empl }\end{array}$ & $\begin{array}{l}\text { the ratio of the } \\
\text { The data come } \\
\text { yed rather }\end{array}$ \\
\hline
\end{tabular}


Table 3

Means of Demographic and Background Characteristics for the Total Sample and for the Sample Stratified by the Values of the State Gas Tax and Car Insurance Variables

\begin{tabular}{|c|c|c|c|c|c|}
\hline & Total Sample & $\begin{array}{r}\text { Low-Tax } \\
\text { States }\end{array}$ & $\begin{array}{r}\text { High-Tax } \\
\text { States }\end{array}$ & $\begin{array}{r}\text { Low- } \\
\text { Insurance } \\
\text { States }\end{array}$ & $\begin{array}{r}\text { High- } \\
\text { Insurance } \\
\text { States }\end{array}$ \\
\hline Car Owners & .691 & .710 & .674 & .729 & .654 \\
\hline Employed & .715 & .721 & .709 & .736 & .695 \\
\hline Hours & 28.687 & 29.219 & 28.177 & 29.391 & 27.985 \\
\hline Log-Wages $^{\mathrm{a}}$ & 2.278 & 2.235 & 2.319 & 2.234 & 2.325 \\
\hline Female & .523 & .533 & .524 & .531 & .526 \\
\hline Married & .549 & .559 & .539 & .567 & .530 \\
\hline Black & .134 & .149 & .119 & .134 & .133 \\
\hline Hispanic & .106 & .091 & .121 & .035 & .178 \\
\hline Education & 13.083 & 13.043 & 13.123 & 13.109 & 13.058 \\
\hline Age & 36.313 & 36.232 & 36.390 & 36.395 & 36.231 \\
\hline Infant & .100 & .101 & .099 & .095 & .104 \\
\hline In School & .157 & .159 & .157 & .150 & .163 \\
\hline Union $^{\mathrm{a}}$ & .149 & .120 & .176 & .136 & .162 \\
\hline \multicolumn{6}{|l|}{ Unemployment } \\
\hline Rate & .065 & .060 & .069 & .058 & .071 \\
\hline Fair Market Rent ${ }^{\mathrm{b}}$ & 566.066 & 511.404 & 618.290 & 478.560 & 653.215 \\
\hline Gas $\operatorname{Tax}^{\mathrm{c}}$ & 20.983 & 17.311 & 24.491 & 19.903 & 22.058 \\
\hline Insurance costs & 750.183 & 727.188 & 772.152 & 614.964 & 884.850 \\
\hline North East & .211 & .123 & .296 & .121 & .301 \\
\hline North Central & .247 & .269 & .227 & .420 & .076 \\
\hline South & .346 & .529 & .170 & .378 & .313 \\
\hline West & .201 & .070 & .326 & .091 & .309 \\
\hline
\end{tabular}

a. Conditional on being employed.

b. Rents computed by the Department of Housing and Urban Development for a just standard 2-bedroom apartment at the 45 th percentile of the rent distribution.

c. Gas taxes are mean taxes per gallon in cents. 
Table 4

OLS and 2SLS Estimates of the Effect of Car Ownership on Employment, Work Hours and Waged

\begin{tabular}{|c|c|c|c|c|c|c|}
\hline & \multicolumn{2}{|c|}{ Employed } & \multicolumn{2}{|c|}{ Hours } & \multicolumn{2}{|c|}{ Log-Wages } \\
\hline & OLS & $2 \mathrm{SLS}$ & OLS & 2SLS & OLS & 2SLS \\
\hline Car-Owner & $\begin{array}{l}.168 \\
(.005)\end{array}$ & $\begin{array}{l}.146 \\
(.076)\end{array}$ & $\begin{array}{l}7.448 \\
(.205)\end{array}$ & $\begin{array}{l}10.791 \\
(2.977)\end{array}$ & $\begin{array}{l}.106 \\
(.006)\end{array}$ & $\begin{array}{l}-.664 \\
(.363)\end{array}$ \\
\hline Female & $\begin{array}{l}-.128 \\
(.004)\end{array}$ & $\begin{array}{l}-.128 \\
(.004)\end{array}$ & $\begin{array}{l}-9.443 \\
(.155)\end{array}$ & $\begin{array}{l}-9.322 \\
(.188)\end{array}$ & $\begin{array}{l}-.222 \\
(.005)\end{array}$ & $\begin{array}{l}-.233 \\
(.008)\end{array}$ \\
\hline Married & $\begin{array}{l}-.061 \\
(.005)\end{array}$ & $\begin{array}{l}-.056 \\
(.017)\end{array}$ & $\begin{array}{l}-2.974 \\
(.187)\end{array}$ & $\begin{array}{l}-3.716 \\
(.675)\end{array}$ & $\begin{array}{l}.065 \\
(.005)\end{array}$ & $\begin{array}{l}.212 \\
(.069)\end{array}$ \\
\hline Black & $\begin{array}{l}-.043 \\
(.006)\end{array}$ & $\begin{array}{l}-.047 \\
(.013)\end{array}$ & $\begin{array}{l}-1.597 \\
(.250)\end{array}$ & $\begin{array}{l}-1.134 \\
(.529)\end{array}$ & $\begin{array}{l}-.088 \\
(.008)\end{array}$ & $\begin{array}{l}-.191 \\
(.047)\end{array}$ \\
\hline Hispanic & $\begin{array}{l}-.022 \\
(.006)\end{array}$ & $\begin{array}{l}-.023 \\
(.009)\end{array}$ & $\begin{array}{l}-.369 \\
(.276)\end{array}$ & $\begin{array}{l}-.160 \\
(.399)\end{array}$ & $\begin{array}{l}-.102 \\
(.009)\end{array}$ & $\begin{array}{l}-.165 \\
(.031)\end{array}$ \\
\hline Education & $\begin{array}{l}.019 \\
(.001)\end{array}$ & $\begin{array}{l}.019 \\
(.002)\end{array}$ & $\begin{array}{l}.966 \\
(.029)\end{array}$ & $\begin{array}{l}.898 \\
(.067)\end{array}$ & $\begin{array}{l}.069 \\
(.001)\end{array}$ & $\begin{array}{l}.080 \\
(.005)\end{array}$ \\
\hline Age & $\begin{array}{l}.042 \\
(.001)\end{array}$ & $\begin{array}{l}.042 \\
(.003)\end{array}$ & $\begin{array}{l}1.998 \\
(.043)\end{array}$ & $\begin{array}{l}1.856 \\
(.131)\end{array}$ & $\begin{array}{l}.056 \\
(.001)\end{array}$ & $\begin{array}{l}.087 \\
(.014)\end{array}$ \\
\hline $\mathrm{Age}^{2}$ & $\begin{array}{l}-.0006 \\
(.00001)\end{array}$ & $\begin{array}{l}-.0006 \\
(.00003)\end{array}$ & $\begin{array}{l}-.026 \\
(.001)\end{array}$ & $\begin{array}{l}-.025 \\
(.001)\end{array}$ & $\begin{array}{l}-.0006 \\
(.00001)\end{array}$ & $\begin{array}{l}-.0009 \\
(.0001)\end{array}$ \\
\hline Infant & $\begin{array}{l}-.107 \\
(.006)\end{array}$ & $\begin{array}{l}-.107 \\
(.006)\end{array}$ & $\begin{array}{l}-4.085 \\
(.268)\end{array}$ & $\begin{array}{l}-4.118 \\
(.269)\end{array}$ & $\begin{array}{l}.032 \\
(.009)\end{array}$ & $\begin{array}{l}.054 \\
(.014)\end{array}$ \\
\hline In School & $\begin{array}{l}-.177 \\
(.006)\end{array}$ & $\begin{array}{l}-.179 \\
(.011)\end{array}$ & $\begin{array}{l}-12.098 \\
(.263)\end{array}$ & $\begin{array}{l}-11.711 \\
(.431)\end{array}$ & $\begin{array}{l}-.115 \\
(.009)\end{array}$ & $\begin{array}{l}-.194 \\
(.038)\end{array}$ \\
\hline Unemployment & $\begin{array}{l}-1.651 \\
(.135)\end{array}$ & $\begin{array}{l}-1.663 \\
(.237)\end{array}$ & $\begin{array}{l}-69.292 \\
(5.598)\end{array}$ & $\begin{array}{l}-65.928 \\
(9.354)\end{array}$ & $\begin{array}{l}-1.764 \\
(.225)\end{array}$ & $\begin{array}{l}-2.018 \\
(.498)\end{array}$ \\
\hline Union & - & - & - & - & $\begin{array}{l}.178 \\
(.007)\end{array}$ & $\begin{array}{l}.211 \\
(.018)\end{array}$ \\
\hline $\begin{array}{l}\text { Fair Market } \\
\text { Rent }\end{array}$ & - & - & - & - & $\begin{array}{l}.0007 \\
(.00002)\end{array}$ & $\begin{array}{l}.0005 \\
(.0001)\end{array}$ \\
\hline $\mathrm{R}^{2}$ & .198 & $.193^{c}$ & .295 & $.317^{\mathrm{c}}$ & .369 & $.284^{\mathrm{c}}$ \\
\hline $\mathrm{N}$ & 47,244 & 47,244 & 47,244 & 47,244 & 33,932 & 33,932 \\
\hline $\begin{array}{l}\text { F-Statistic } \\
\text { (P-value) }\end{array}$ & - & $\begin{array}{l}94.553 \\
(.0001)\end{array}$ & - & $\begin{array}{l}107.732 \\
(.0001)\end{array}$ & - & $\begin{array}{l}7.065 \\
(.0009)\end{array}$ \\
\hline $\begin{array}{l}\text { Overid. Test } \\
\text { (P-value) }\end{array}$ & - & $\begin{array}{l}1.089 \\
(.310)\end{array}$ & - & $\begin{array}{l}2.227 \\
(.136)\end{array}$ & - & $\begin{array}{l}3.232 \\
(.072)\end{array}$ \\
\hline
\end{tabular}

All regressions include a constant. Models are estimated using a grouped error structure.

a. The F-statistics are from tests of the collective significance of the gas-tax and insurance instruments in the first-stage regressions.

b. This is an F-statistic for the over identifying restrictions test of Basmann (1960).

c. Calculated by applying the FGIV parameter estimates to the undifferenced data. 
Table 5

OLS and 2SLS Estimates of the Effect of Car Ownership on Employment, Work Hours and Wages, by Gender

\begin{tabular}{cccccc}
\multicolumn{2}{c}{ Employed } & \multicolumn{2}{c}{ Hours } & \multicolumn{2}{c}{ Log-Wages } \\
\hline OLS & 2SLS & OLS & 2SLS & OLS & 2SLS \\
\hline
\end{tabular}

\begin{tabular}{|c|c|c|c|c|c|c|}
\hline \multicolumn{7}{|l|}{ A. All } \\
\hline Car-Owner & $\begin{array}{l}.168 \\
(.005)\end{array}$ & $\begin{array}{l}.146 \\
(.076)\end{array}$ & $\begin{array}{l}7.448 \\
(.205)\end{array}$ & $\begin{array}{l}10.791 \\
(2.977)\end{array}$ & $\begin{array}{l}.106 \\
(.006)\end{array}$ & $\begin{array}{l}-.664 \\
(.363)\end{array}$ \\
\hline $\begin{array}{l}\text { F-Statistic } \\
\text { (P-value) }\end{array}$ & - & $\begin{array}{l}94.553 \\
(.0001)\end{array}$ & - & $\begin{array}{l}107.732 \\
(.0001)\end{array}$ & - & $\begin{array}{l}7.065 \\
(.0009)\end{array}$ \\
\hline $\begin{array}{l}\text { Overid. Test }{ }^{\mathrm{b}} \\
\text { (P-value) }\end{array}$ & - & $\begin{array}{l}1.089 \\
(.310)\end{array}$ & - & $\begin{array}{l}2.227 \\
(.136)\end{array}$ & - & $\begin{array}{l}3.232 \\
(.072)\end{array}$ \\
\hline \multicolumn{7}{|l|}{ B. Men } \\
\hline Car-Owner & $\begin{array}{l}.142 \\
(.006)\end{array}$ & $\begin{array}{l}.126 \\
(.095)\end{array}$ & $\begin{array}{l}6.339 \\
(.298)\end{array}$ & $\begin{array}{l}9.411 \\
(4.211)\end{array}$ & $\begin{array}{l}.119 \\
(.010)\end{array}$ & $\begin{array}{l}-.338 \\
(.377)\end{array}$ \\
\hline $\begin{array}{l}\text { F-Statistic } \\
\text { (P-value) }\end{array}$ & - & $\begin{array}{l}53.852 \\
(.0001)\end{array}$ & - & $\begin{array}{l}54.214 \\
(.0001)\end{array}$ & - & $\begin{array}{l}6.324 \\
(.001)\end{array}$ \\
\hline $\begin{array}{l}\text { Overid. Test } \\
\text { (P-value) }\end{array}$ & - & $\begin{array}{l}.114 \\
(.735)\end{array}$ & - & $\begin{array}{l}3.029 \\
(.081)\end{array}$ & - & $\begin{array}{l}2.523 \\
(.112)\end{array}$ \\
\hline \multicolumn{7}{|l|}{ C. Women } \\
\hline Car-Owner & $\begin{array}{l}.174 \\
(.007)\end{array}$ & $\begin{array}{l}.166 \\
(.086)\end{array}$ & $\begin{array}{l}7.614 \\
(.273)\end{array}$ & $\begin{array}{l}11.278 \\
(3.547)\end{array}$ & $\begin{array}{l}.090 \\
(.009)\end{array}$ & $\begin{array}{l}-.691 \\
(.360)\end{array}$ \\
\hline $\begin{array}{l}\text { F-Statistic } \\
\text { (P-value) }\end{array}$ & - & $\begin{array}{l}79.223 \\
(.0001)\end{array}$ & - & $\begin{array}{l}71.836 \\
(.0001)\end{array}$ & - & $\begin{array}{l}6.870 \\
(.001)\end{array}$ \\
\hline $\begin{array}{l}\text { Overid. Test }{ }^{\mathrm{b}} \\
\text { (P-value) }\end{array}$ & - & $\begin{array}{l}2.852 \\
(.092)\end{array}$ & - & $\begin{array}{l}.485 \\
(.486)\end{array}$ & - & $\begin{array}{l}2.271 \\
(.131)\end{array}$ \\
\hline
\end{tabular}

All regressions include a constant and all variables included in the specifications in Table 4. Models are estimated using a grouped error structure.

a. The F-statistics are from tests of the collective significance of the gas-tax and insurance instruments in the first-stage regressions.

b. This is an F-statistic for the over identifying restrictions test of Basmann (1960). 


\begin{tabular}{|c|c|c|c|}
\hline \multicolumn{4}{|c|}{$\begin{array}{l}\text { Table } 6 \\
\text { Means of Demographic and Background Characteristics by Position in the Imputed Earnings } \\
\text { Distribution }\end{array}$} \\
\hline & Bottom Third & Middle Third & Upper Third \\
\hline Car Owners & .438 & .769 & .870 \\
\hline Employed & .539 & .754 & .854 \\
\hline Hours & 19.274 & 29.985 & 36.900 \\
\hline Log-Wages $^{a}$ & 1.850 & 2.214 & 2.622 \\
\hline Female & .654 & .616 & .313 \\
\hline Married & .337 & .617 & .695 \\
\hline Black & .200 & .145 & .054 \\
\hline Hispanic & .194 & .087 & .037 \\
\hline Education & 11.171 & 12.721 & 15.380 \\
\hline Age & 28.996 & 39.178 & 41.853 \\
\hline Infant & .133 & .083 & .083 \\
\hline In School & .316 & .073 & .079 \\
\hline Union $^{\mathrm{a}}$ & .082 & .147 & .194 \\
\hline Unemployment Rate & .065 & .064 & .064 \\
\hline Fair Market Rent ${ }^{b}$ & 566.695 & 561.480 & 570.019 \\
\hline Gas $\operatorname{Tax}^{\mathrm{c}}$ & 20.939 & 20.921 & 21.088 \\
\hline Insurance costs & 753.67 & 744.912 & $7 \overline{5} 1.929$ \\
\hline North East & .196 & .209 & .228 \\
\hline North Central & .232 & .258 & .252 \\
\hline South & .365 & .348 & .324 \\
\hline West & .210 & .189 & .204 \\
\hline
\end{tabular}

a. Conditional on being employed.

b. Rents computed by the Department of Housing and Urban Development for a just standard 2-bedroom apartment at the 45th percentile of the rent distribution.

c. Gas taxes are mean taxes per gallon in cents. 
Table 7

OLS and 2SLS Estimates of the Effect of Car Ownership on Employment, Work Hours and Wages, by Position in the Imputed Earnings Distribution

\begin{tabular}{|c|c|c|c|c|c|c|}
\hline & \multicolumn{2}{|c|}{ Employed } & \multicolumn{2}{|c|}{ Hours } & \multicolumn{2}{|c|}{ Log-Wages } \\
\hline & OLS & 2SLS & OLS & 2SLS & OLS & 2SLS \\
\hline \multicolumn{7}{|l|}{ Bottom Third } \\
\hline Car-Owner & $\begin{array}{l}.213 \\
(.008)\end{array}$ & $\begin{array}{l}.195 \\
(.111)\end{array}$ & $\begin{array}{l}9.066 \\
(.319)\end{array}$ & $\begin{array}{l}8.725 \\
(4.741)\end{array}$ & $\begin{array}{l}.096 \\
(.009)\end{array}$ & $\begin{array}{l}-.319 \\
(.258)\end{array}$ \\
\hline $\begin{array}{l}\text { F-Statistic } \\
\text { (P-value) }\end{array}$ & - & $\begin{array}{l}50.026 \\
(.0001)\end{array}$ & - & $\begin{array}{l}35.086 \\
(.0001)\end{array}$ & - & $\begin{array}{l}8.128 \\
(.0003)\end{array}$ \\
\hline $\begin{array}{l}\text { Overid. Test } \\
\text { (P-value) }\end{array}$ & - & $\begin{array}{l}1.007 \\
(.315)\end{array}$ & - & $\begin{array}{l}1.394 \\
(.237)\end{array}$ & - & $\begin{array}{l}2.143 \\
(.143)\end{array}$ \\
\hline \multicolumn{7}{|l|}{ Middle Third } \\
\hline Car-Owner & $\begin{array}{l}.159 \\
(.008)\end{array}$ & $\begin{array}{l}.172 \\
(.079)\end{array}$ & $\begin{array}{l}7.551 \\
(.358)\end{array}$ & $\begin{array}{l}13.645 \\
(3.579)\end{array}$ & $\begin{array}{l}.160 \\
(.012)\end{array}$ & $\begin{array}{l}-.229 \\
(.356)\end{array}$ \\
\hline $\begin{array}{l}\text { F-Statistica } \\
\text { (P-value) }\end{array}$ & - & $\begin{array}{l}91.281 \\
(.0001)\end{array}$ & - & $\begin{array}{l}80.747 \\
(.0001)\end{array}$ & - & $\begin{array}{l}6.809 \\
(.0011)\end{array}$ \\
\hline $\begin{array}{l}\text { Overid. Test }{ }^{\mathrm{b}} \\
\text { (P-value) }\end{array}$ & - & $\begin{array}{l}1.534 \\
(.215)\end{array}$ & - & $\begin{array}{l}2.838 \\
(.092)\end{array}$ & - & $\begin{array}{l}2.326 \\
(.127)\end{array}$ \\
\hline \multicolumn{7}{|l|}{ Top Third } \\
\hline Car-Owner & $\begin{array}{l}.099 \\
(.008)\end{array}$ & $\begin{array}{l}.142 \\
(.074)\end{array}$ & $\begin{array}{l}4.665 \\
(.411)\end{array}$ & $\begin{array}{l}12.900 \\
(3.962)\end{array}$ & $\begin{array}{l}.122 \\
(.016)\end{array}$ & $\begin{array}{l}-.957 \\
(.505)\end{array}$ \\
\hline $\begin{array}{l}\text { F-Statistica } \\
\text { (P-value) }\end{array}$ & - & $\begin{array}{l}96.992 \\
(.0001)\end{array}$ & - & $\begin{array}{l}80.918 \\
(.0001)\end{array}$ & - & $\begin{array}{l}3.746 \\
(.023)\end{array}$ \\
\hline $\begin{array}{l}\text { Overid. Test }{ }^{\mathrm{b}} \\
\text { (P-value) }\end{array}$ & - & $\begin{array}{l}1.711 \\
(.190)\end{array}$ & - & $\begin{array}{l}.137 \\
(.712)\end{array}$ & - & $\begin{array}{l}.146 \\
(.703)\end{array}$ \\
\hline
\end{tabular}

All regressions include a constant and all variables included in the specification in Table 4. Models are estimated using a grouped error structure.

a. The F-statistics are from tests of the collective significance of the gas-tax and insurance instruments in the first-stage regressions.

b. This is an F-statistic for the over identifying restrictions test of Basmann (1960). 
Table A1

Means Demographic Characteristics of Individuals With and Without Cars

\begin{tabular}{lrrr}
\hline & Total Sample & With Cars & Without Cars \\
\hline Female & .523 & .522 & .541 \\
Married & .549 & .694 & .223 \\
Black & .134 & .089 & .232 \\
Hispanic & .106 & .080 & .165 \\
Education & 13.083 & 13.461 & 12.236 \\
Age & 36.313 & 39.497 & 29.169 \\
Infant & .100 & .101 & .096 \\
In School & .157 & .076 & .337 \\
\hline \hline
\end{tabular}




\begin{tabular}{|c|c|c|c|}
\hline & $\begin{array}{l}\text { Results from } \\
\text { Employment Model }\end{array}$ & $\begin{array}{l}\text { Results from Hours } \\
\text { Model }\end{array}$ & $\begin{array}{l}\text { Results from Log-Wage } \\
\text { Model }\end{array}$ \\
\hline Gas Tax & $\begin{array}{l}-.0032 \\
(.0006)\end{array}$ & $\begin{array}{l}-.0034 \\
(.0005)\end{array}$ & $\begin{array}{l}-.0023 \\
(.0009)\end{array}$ \\
\hline Insurance Costs & $\begin{array}{l}-.0002 \\
(.00002)\end{array}$ & $\begin{array}{l}-.0002 \\
(.00002)\end{array}$ & $\begin{array}{l}-.0001 \\
(.00004)\end{array}$ \\
\hline Female & $\begin{array}{l}-.0363 \\
(.0034)\end{array}$ & $\begin{array}{l}-.0363 \\
(.0034)\end{array}$ & $\begin{array}{l}-.0152 \\
(.0039)\end{array}$ \\
\hline Married & $\begin{array}{l}.2169 \\
(.0040)\end{array}$ & $\begin{array}{l}.2170 \\
(.0040)\end{array}$ & $\begin{array}{l}.1906 \\
(.0044)\end{array}$ \\
\hline Black & $\begin{array}{l}-.1570 \\
(.0056)\end{array}$ & $\begin{array}{l}-.1575 \\
(.0056)\end{array}$ & $\begin{array}{l}-.1286 \\
(.0067)\end{array}$ \\
\hline Hispanic & $\begin{array}{l}-.0898 \\
(.0062)\end{array}$ & $\begin{array}{l}-.0894 \\
(.0062)\end{array}$ & $\begin{array}{l}-.0802 \\
(.0076)\end{array}$ \\
\hline Education & $\begin{array}{l}.0208 \\
(.0006)\end{array}$ & $\begin{array}{l}.0209 \\
(.0006)\end{array}$ & $\begin{array}{l}.0148 \\
(.0007)\end{array}$ \\
\hline Age & $\begin{array}{l}.0421 \\
(.0009)\end{array}$ & $\begin{array}{l}.0421 \\
(.0009)\end{array}$ & $\begin{array}{l}.0395 \\
(.0011)\end{array}$ \\
\hline $\mathrm{Age}^{2}$ & $\begin{array}{l}-.0004 \\
(.00001)\end{array}$ & $\begin{array}{l}-.0004 \\
(.00001)\end{array}$ & $\begin{array}{l}-.0004 \\
(.00001)\end{array}$ \\
\hline Infant & $\begin{array}{l}.0090 \\
(.0059)\end{array}$ & $\begin{array}{l}.0091 \\
(.0059)\end{array}$ & $\begin{array}{l}.0282 \\
(.0071)\end{array}$ \\
\hline In School & $\begin{array}{l}-.1140 \\
(.0058)\end{array}$ & $\begin{array}{l}-.1139 \\
(.0058)\end{array}$ & $\begin{array}{l}-.1027 \\
(.0071)\end{array}$ \\
\hline Unemployment & $\begin{array}{l}.0573 \\
(.2276)\end{array}$ & $\begin{array}{l}.0883 \\
(.2172)\end{array}$ & $\begin{array}{l}-.0252 \\
(.3458)\end{array}$ \\
\hline Union & - & - & $\begin{array}{l}.0467 \\
(.0056)\end{array}$ \\
\hline Fair Market Rent & - & - & $\begin{array}{l}-.0001 \\
(.00005)\end{array}$ \\
\hline $\mathrm{R}^{2}$ & $.332^{\mathrm{b}}$ & $.333^{\mathrm{b}}$ & $.120^{\mathrm{b}}$ \\
\hline $\mathrm{N}$ & 47,244 & 47,244 & 33,932 \\
\hline $\begin{array}{l}\text { F-Statistic } \\
\text { (P-value) }\end{array}$ & $\begin{array}{l}94.553 \\
(.0001)\end{array}$ & $\begin{array}{l}107.723 \\
(.0001)\end{array}$ & $\begin{array}{l}7.065 \\
(.0009)\end{array}$ \\
\hline
\end{tabular}

All regression include a constant. All models include random state-year effects.

a. The F-statistics are from tests of the collective significance of the gas-tax and insurance instruments. b. Calculated by applying the FGIV parameter estimates to the undifferenced data. 
Table A3

First-Stage Regression Results from 2SLS Models Estimated by Position in the Imputed Earnings Distribution

\begin{tabular}{|c|c|c|c|}
\hline & Employment & Hours & Wages \\
\hline \multicolumn{4}{|l|}{ Bottom Third } \\
\hline Gas Tax & $\begin{array}{l}-.0056 \\
(.0008)\end{array}$ & $\begin{array}{l}-.0051 \\
(.0010)\end{array}$ & $\begin{array}{l}-.0044 \\
(.0014)\end{array}$ \\
\hline Insurance Costs & $\begin{array}{l}-.0002 \\
(.00003)\end{array}$ & $\begin{array}{l}-.0002 \\
(.00003)\end{array}$ & $\begin{array}{l}-.0002 \\
(.00007)\end{array}$ \\
\hline F-Statistic ${ }^{a}$ & $\begin{array}{l}50.026 \\
(.0001)\end{array}$ & $\begin{array}{l}35.087 \\
(.0001)\end{array}$ & $\begin{array}{l}8.128 \\
(.0003)\end{array}$ \\
\hline \multicolumn{4}{|l|}{ Middle Third } \\
\hline Gas Tax & $\begin{array}{l}-.0046 \\
(.0007)\end{array}$ & $\begin{array}{l}-.0044 \\
(.0008)\end{array}$ & $\begin{array}{l}-.0034 \\
(.0012)\end{array}$ \\
\hline Insurance Costs & $\begin{array}{l}-.0003 \\
(.00002)\end{array}$ & $\begin{array}{l}-.0003 \\
(.00002)\end{array}$ & $\begin{array}{l}-.0001 \\
(.00005)\end{array}$ \\
\hline F-Statistic ${ }^{a}$ & $\begin{array}{l}91.281 \\
(.0001)\end{array}$ & $\begin{array}{l}80.747 \\
(.0001)\end{array}$ & $\begin{array}{l}6.809 \\
(.0011)\end{array}$ \\
\hline \multicolumn{4}{|l|}{ Top Third } \\
\hline Gas Tax & $\begin{array}{l}-.0029 \\
(.0005)\end{array}$ & $\begin{array}{l}-.0027 \\
(.0006)\end{array}$ & $\begin{array}{l}-.0011 \\
(.0009)\end{array}$ \\
\hline Insurance Costs & $\begin{array}{l}-.0002 \\
(.00002)\end{array}$ & $\begin{array}{l}-.0002 \\
(.00002)\end{array}$ & $\begin{array}{l}-.0001 \\
(.00004)\end{array}$ \\
\hline F-Statistic ${ }^{a}$ & $\begin{array}{l}96.992 \\
(.0001)\end{array}$ & $\begin{array}{l}80.918 \\
(.0001)\end{array}$ & $\begin{array}{l}3.746 \\
(.0236)\end{array}$ \\
\hline
\end{tabular}

All regressions include a constant and all variables included in the specification in Table A2. Models are estimated using a grouped error structure.

a. The F-statistics are from tests of the collective significance of the gas-tax and insurance instruments in the first-stage regressions. 